\title{
Chronic lymphocytic leukaemia with concomitant plasmablastic lymphoma
}

\begin{tabular}{|c|c|}
\hline \multicolumn{2}{|c|}{$\begin{array}{l}\text { Authors: } \\
\text { Jacqueline Goedhals } \\
\text { Leriska Haupt }^{2,3} \\
\text { Deborah Jafta }^{4}\end{array}$} \\
\hline \multicolumn{2}{|c|}{$\begin{array}{l}\text { Affiliations: } \\
{ }^{1} \text { Department of Anatomical } \\
\text { Pathology, Faculty of Health } \\
\text { Sciences, University of the } \\
\text { Free State, South Africa }\end{array}$} \\
\hline \multicolumn{2}{|c|}{$\begin{array}{l}{ }^{2} \text { Department of Haematology } \\
\text { and Cell Biology, Faculty of } \\
\text { Health Sciences, University of } \\
\text { the Free State, South Africa }\end{array}$} \\
\hline \multicolumn{2}{|c|}{$\begin{array}{l}{ }^{3} \text { National Health Laboratory } \\
\text { Service, South Africa }\end{array}$} \\
\hline \multicolumn{2}{|c|}{$\begin{array}{l}{ }^{4} \text { Van Rensburg Pathologists, } \\
\text { South Africa }\end{array}$} \\
\hline \multicolumn{2}{|c|}{$\begin{array}{l}\text { Corresponding author: } \\
\text { Jacqueline Goedhals, } \\
\text { gnmbjg@ufs.ac.za }\end{array}$} \\
\hline \multicolumn{2}{|c|}{$\begin{array}{l}\text { Dates: } \\
\text { Received: } 10 \text { Jan. } 2016 \\
\text { Accepted: } 07 \text { Feb. } 2016 \\
\text { Published: } 03 \text { Feb. } 2017\end{array}$} \\
\hline \multicolumn{2}{|c|}{$\begin{array}{l}\text { How to cite this article: } \\
\text { Goedhals J, Haupt L, Jafta D. } \\
\text { Chronic lymphocytic } \\
\text { leukaemia with concomitant } \\
\text { plasmablastic lymphoma. S. } \\
\text { Afr. j. oncol. 2017;1(0), a8. } \\
\text { https://doi.org/10.4102/sajo. } \\
\text { v1i0.8 }\end{array}$} \\
\hline \multicolumn{2}{|c|}{$\begin{array}{l}\text { Copyright: } \\
\text { (C) 2017. The Authors } \\
\text { Licensee: AOSIS. This } \\
\text { is licensed under the } \\
\text { Creative Commons } \\
\text { Attribution License. }\end{array}$} \\
\hline \multicolumn{2}{|l|}{ Read online: } \\
\hline 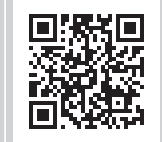 & $\begin{array}{l}\text { Scan this QR } \\
\text { code with your } \\
\text { smart phone or } \\
\text { mobile device } \\
\text { to read online. }\end{array}$ \\
\hline
\end{tabular}

Plasmablastic lymphomas are high-grade lymphomas that usually occur in immunesuppressed patients. Occasionally, they can arise from an underlying haematolymphoid malignancy, termed 'transformed plasmablastic lymphoma'. In this report, we describe a case of chronic lymphocytic leukaemia and plasmablastic lymphoma in an elderly HIV-negative patient.

\section{Introduction}

Plasmablastic lymphoma (PBL) is a high-grade lymphoma most often associated with HIV infection. It can also occur secondary to iatrogenic immune suppression in organ transplant patients and in elderly patients, and secondary to existing lymphoproliferative and autoimmune disorders. ${ }^{1}$ In a minority of cases, PBL can arise from another haematological malignancy, termed 'transformed PBL'. In most of these cases, PBL has evolved from chronic lymphocytic leukaemia/ small lymphocytic lymphoma (CLL/SLL) but cases of PBL have also been associated with follicular lymphoma and plasmacytoma. ${ }^{1}$ CLL/SLL transforms into a high-grade lymphoma in $2.2 \%-8 \%$ of cases. ${ }^{2}$ This is known as Richter transformation and was first described in 1928 by Maurice Richter. ${ }^{3}$ In most cases, a diffuse large B-cell lymphoma supervenes. However, Hodgkin lymphoma, prolymphocytic leukaemia, lymphoblastic lymphoma and hairy cell leukaemia can also develop. ${ }^{2}$

\section{Case report}

A 72-year-old HIV-negative female patient was referred to Universitas Academic Hospital in Bloemfontein, South Africa, from a peripheral hospital in the Free State Province, with a diagnosis of pneumonia, a white blood cell count of $138 \times 10^{9} / \mathrm{L}$, a lymphocyte count of $129 \times 10^{9} / \mathrm{L}$ and a neutrophil count of $9.72 \times 10^{9} / \mathrm{L}$. Immunophenotyping performed on peripheral blood demonstrated a monoclonal B-lymphocyte population which was positive for CD5, CD19, CD20 and CD23. Kappa light chain restriction was found and a diagnosis of CLL was made. Both the peripheral smear and a May-Grünwald-Giemsa stain of the bone marrow aspirate showed an increase in small lymphocytes consistent with the diagnosis of CLL, interspersed with scattered large cells with pleomorphic nuclei and basophilic cytoplasm resembling blasts (Figure 1). The possibility of Richter syndrome was raised. Bone marrow biopsy (Figure 2a) demonstrated sheets of large pleomorphic cells with prominent nucleoli. Numerous apoptotic bodies were noted. Immunohistochemical stains for CD138 (Figure 2b), LCA, CD79a, Epithelial Membrane Antigen (EMA) and Multiple Myeloma Oncogene 1(MUM1) were positive, and the Ki67 proliferation index was 90\%. Kappa light chain restriction was confirmed with in situ hybridisation. CD20, CD3, ALK, PAX5, CD56 and HHV8 were negative and in situ hybridisation for Epstein-Barr virus (EBER) was also negative. A diagnosis of PBL was made. The patient was not on any immunosuppressive therapy, and there was no history of autoimmune disorders. The rheumatoid factor was negative. She subsequently developed septicaemia and Escherichia coli was isolated from blood culture. Renal failure then supervened with hyperkalaemia, metabolic acidosis and uraemic encephalopathy. She died 3 days after admission.

\section{Ethical consideration}

Approval to report the case was obtained from the Health Sciences Research Committee, Faculty of Health Sciences, University of the Free State (ECUFS NR 105/2013); the head of clinical services, Universitas Academic Hospital, gave consent as none of the patient's relatives could be located.

\section{Discussion}

PBL is a specific subtype of diffuse large B-cell lymphoma. Although PBL can occur at any age, the vast majority of patients are adults. Seventy-five per cent of published cases have occurred in 

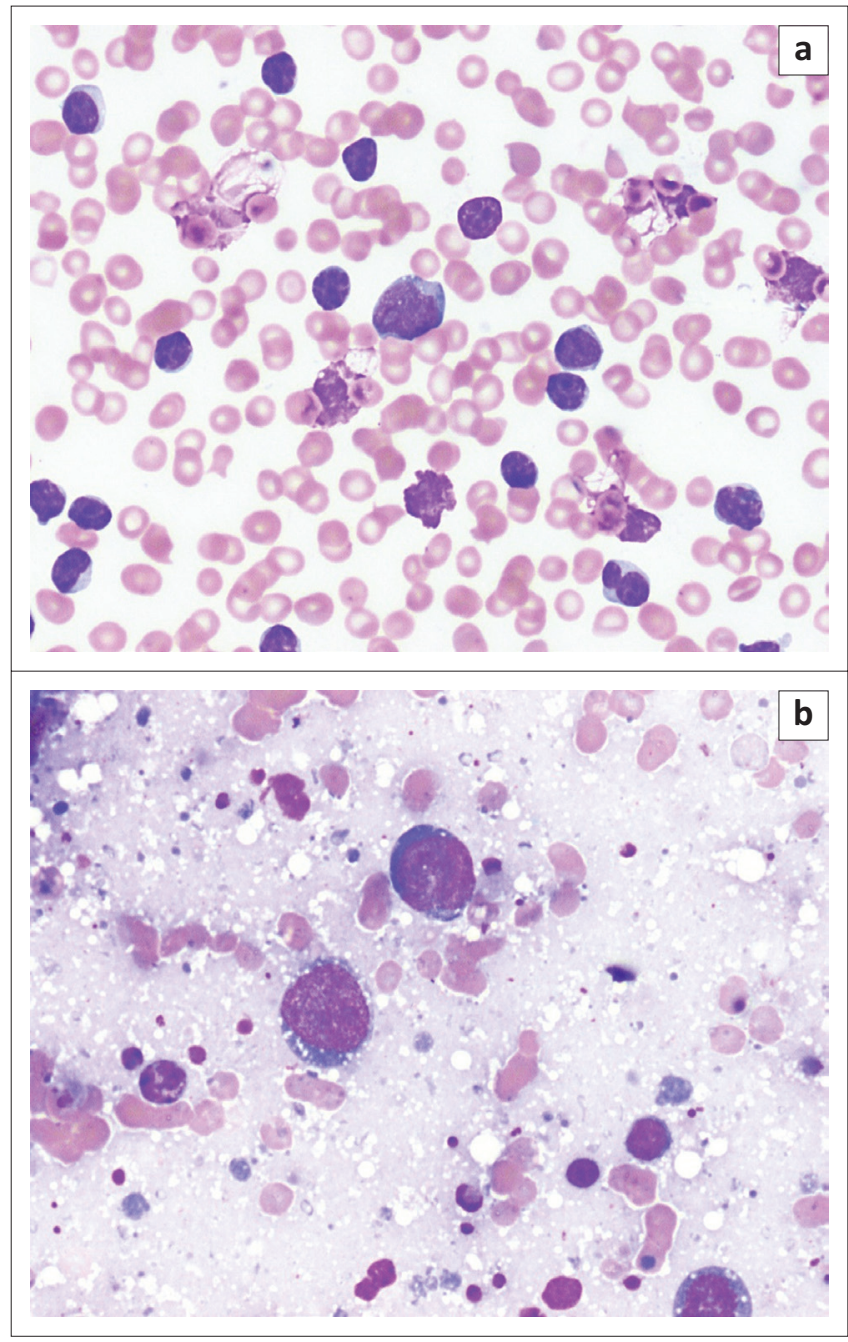

FIGURE 1: Peripheral smear (a) and bone marrow imprint (b) demonstrating scattered large atypical cells with pleomorphic nuclei resembling blasts (MayGrünwald-Giemsa stain).

male patients. ${ }^{1}$ The prognosis is extremely poor with a median overall survival of less than 1 year. $^{1}$

The differential diagnosis on histology includes diffuse large B-cell lymphoma, anaplastic large-cell lymphoma, extracavitary primary effusion lymphoma and anaplastic multiple myeloma. PBLs are positive with plasma cell markers such as CD138 and CD38 and are also often CD79a, MUM1 and EMA positive. They are negative for B-cell markers such as CD20 and PAX-5, whereas diffuse large B-cell lymphomas are positive for B-cell markers and negative for CD138 and CD38. Anaplastic large-cell lymphomas are CD30 and often ALK-1 positive and are negative for B-cell and plasma cell markers, whereas PBL is always negative for ALK-1 although CD30 can be positive in a subset of cases. $\mathrm{HHV} 8$ is negative in PBL and can be used to exclude primary effusion lymphoma which is HHV8 positive. Distinguishing PBL from anaplastic multiple myeloma can be problematic. CD56 is usually negative in PBL and positive in anaplastic multiple myeloma. Sixty-six per cent of PBLs are EBER-ISH positive, and when present, positivity favours a diagnosis of PBL. Clinical features such as monoclonal paraproteinaemia, hypercalcaemia and renal involvement favour myeloma. ${ }^{1}$

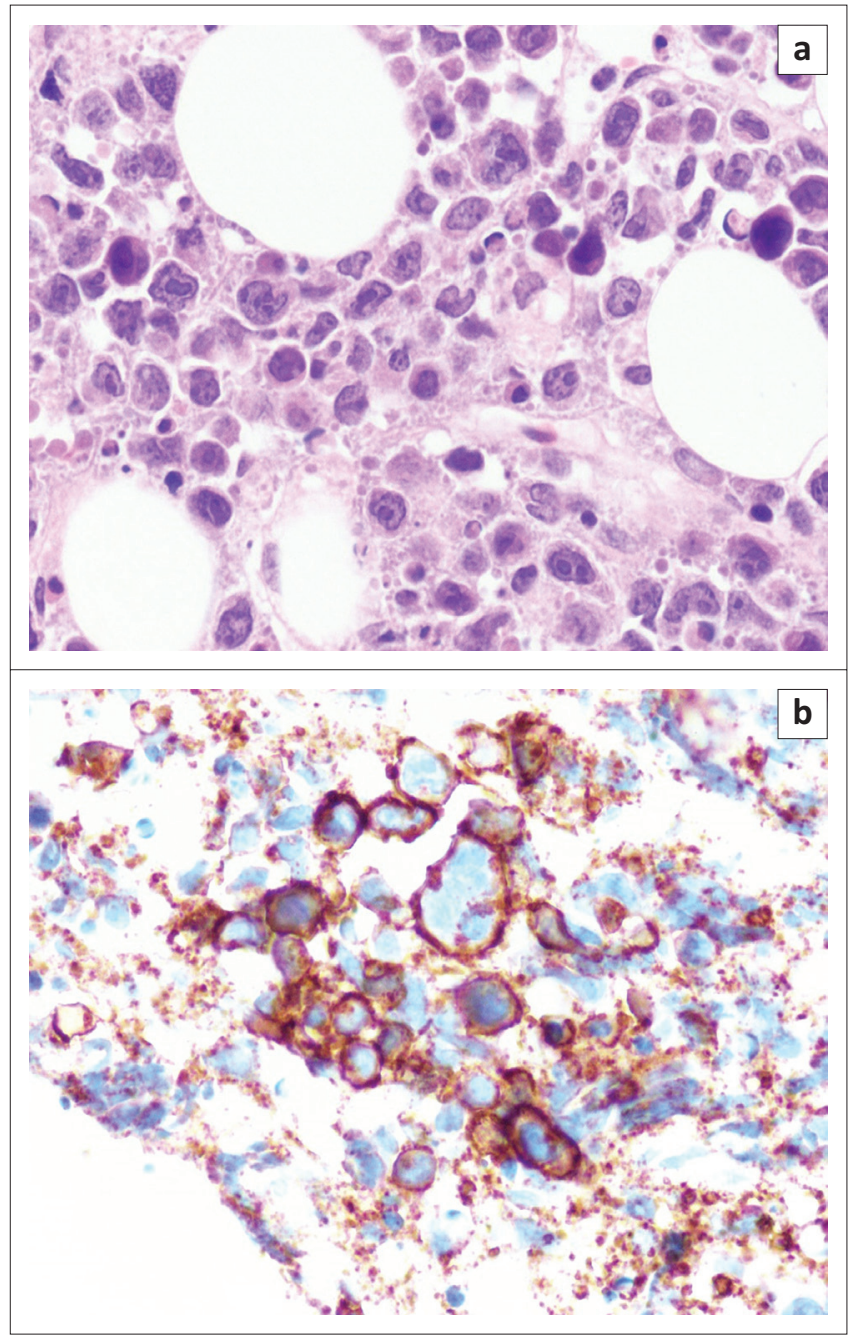

FIGURE 2: Haematoxylin and eosin (H\&E) stain of a section of the bone marrow biopsy demonstrating sheets of pleomorphic cells with prominent nucleoli and scattered apoptotic bodies (a). CD138 immunohistochemical stain with strong membrane positivity (b).

Eight cases of PBL occurring in patients with CLL/SLL have been described previously, of which six were men. $4,5,6,7,7,9$ The patients' ages ranged from 42 to 70 years. Six patients were HIV-negative, and in two cases the HIV status was not mentioned. Four patients had received chemotherapy for CLL/SLL prior to developing PBL, whereas the diagnosis of CLL/SLL and PBL was made simultaneously in three patients. In one case, no reference was made as to whether prior chemotherapy had been given, although the CLL/SLL had been diagnosed a number of years before the development of the PBL. The PBL was diagnosed in a mediastinal lymph node biopsy in one patient, whereas the remaining patients presented with subcutaneous, mandibular (two patients), nasopharyngeal, mediastinal, gastro-oesophageal junction and supraclavicular involvement. Two of the cases were EBER-positive, and one was positive for HHV8. All eight patients died within 24 months after diagnosis of PBL. ${ }^{4,5,6,7,8,9}$

In our case, the patient was an elderly HIV-negative woman, and the CLL and PBL were diagnosed concurrently, with the PBL being identified on the bone marrow biopsy. The PBL component was negative for both HHV8 and EBER. The fact 
that kappa light chain restriction was noted in both the CLL and PBL components would suggest clonal transformation of the CLL to PBL.

In conclusion, PBL may rarely occur in patients with CLL/ SLL or another underlying haematological malignancy and is termed 'transformed PBL'. Although rare, Richter syndrome is a serious complication of CLL/SLL and any larger, atypical cells on peripheral blood or bone marrow aspirate should be investigated to ensure the diagnosis is not missed and inappropriate treatment administered.

\section{Acknowledgements}

The authors thank Dr Daleen Struwig, medical writer and editor, Faculty of Health Sciences, University of the Free State, for technical and editorial preparation of the manuscript.

\section{Competing interests}

The authors declare that they have no financial or personal relationships that may have inappropriately influenced them in writing this article.

\section{Authors' contributions}

J.G. diagnosed the plasmablastic lymphoma and is the main author. L.H. and D.J. diagnosed the chronic lymphocytic leukaemia. D.J. obtained ethical approval to report the case. L.H. provided input from a haematological perspective.

\section{References}

1. Castillo JJ, Bibas M, Miranda RN. The biology and treatment of plasmablastic lymphoma. Blood. 2015;125(15):2323-2330. http://dx.doi.org/10.1182/blood2014-10-567479

2. Tsimberidou AM, Keating MJ. Richter syndrome: Biology, incidence and therapeutic strategies. Cancer. 2005;103(2):216-228. http://dx.doi.org/10.1002/cncr.20773

3. Richter MN. Generalized reticular cell sarcoma of lymph nodes associated with lymphatic leukaemia. Am J Pathol. 1928;4(4):285-292.

4. Robak T, Urbańska-Rys $\mathrm{H}$, Strzelencka B, et al. Plasmablstic lymphoma in a patient with chronic lymphocytic leukaemia heavily pretreated with cladribine (2-CdA): An unusual variant of Richter's syndrome. Eur J Haematol. 2001;67(5-6):322-327. $\mathrm{http}: / / \mathrm{dx}$.doi.org/10.1034/j.1600-0609.2001.00592.x

5. Ramalingam $P$, Nayak-Kapoor A, Reid-Nicholson $M$, Jones-Crawford J, Ustun C. Plasmablastic lymphoma with small lymphocytic lymphoma: Clinico-pathologic features, and review of the literature. Leuk Lymphoma. 2008;49(10):1999-2002. $\mathrm{http}: / /$ dx.doi.org/10.1080/10428190802251795

6. Foo WC, Huang $Q$, Sebastian $S$, Hutchinson $C B$, Burchette J, Wang E. Concurrent classical Hodgkin lymphoma and plasmablastic lymphoma in a patient with chronic lymphocytic leukaemia/small lymphocytic lymphoma treated with fludarabine: A dimorphic presentation of iatrogenic immunodeficiency-associated lymphoproliferative disorder with evide of B cells by Epstein-Barr virus. Hum Pathol. 2010;41(12):1802-1808. http:// dx.doi.org/10.1016/j.humpath.2010.04.019

7. Martinez D, Valera A, Perez NS, et al. Plasmablastic transformation of low-grade B-cell lymphomas. Report on 6 cases. Am J Surg Pathol. 2013;37(2):272-281. http://dx.doi.org/10.1097/PAS.0b013e31826cb1d1

8. Holderness BM, Malhotra S, Levy NB, Danilov AV. Bretuximab vedotin demonstrates activity in a patient with plasmablastic lymphoma arising in a background of chronic lymphocytic leukaemia. J Clin Oncol. 2013;31(12):e197e199. http://dx.doi.org/10.1200/JCO.2012.46.9593

9. Pan Z, Xie $Q$, Reperinger S, Richendollar BG, Chan WC, Huang Q. Plasmablastic transformation of low-grade CD5+ B-cell lymphoproliferative disorder with MYC gene rearrangements. Hum Pathol. 2013;44(10):2139-2148. http://dx.doi. org/10.1016/j.humpath.2013.04.008 